\title{
Pengaruh Konsentrasi dan Lama Waktu Penggaraman Terhadap Mutu Ikan Terbang (Hirundichthys Oxchepalus) Asin Kering
}

\section{The Effect of Concentration and Length of Salting Time on the Quality of Dried Salted (Hirundichthys Oxchepalus) Flying Fish}

\author{
Retno Ningrum, Program Studi Pendidikan Teknologi Pertanian Fakultas Teknik, Universitas \\ Negeri Makassar. Emai: Retnoningrumptp01@gmail.com \\ Lahming, Program Studi Pendidikan Teknologi Pertanian Fakultas Teknik, Universitas \\ Negeri Makassar. Emai: \\ Amirah Mustarin, Program Studi Pendidikan Teknologi Pertanian Fakultas Teknik, \\ Universitas Negeri Makassar. Emai:
}

\begin{abstract}
Abstrak
Penelitian ini bertujuan untuk mengevaluasi dan menganalisis pengaruh konsentrasi garam dan lama penggaraman terhadap mutu dan nilai organoleptie ikan terbang asin kering. Penelitian ini merupakan (RAL Faktorial) yang terdiri dari dua faktor. Faktor A dengan konsentrasi garam $(27 \%, 34 \%$, dan $41 \%)$ dan Faktor B dengan lama penggaraman (3 jam, 6 jam, dan 24 jam) dilakukan dengan 9 perlakuan dan 3 kali ulangan. Variabel yang diamati adalah uji kadar air, uji kadar protein, uji kadar garam, dan uji organoleptik. Teknik analisis yang digunakan dalam penelitian ini adalah analisis sidik ragam yang diolah dengan menggunakan SPSS versi 22. Hasil penelitian untuk uji kadar air dan kadar protein dengan penambahan konsentrasi garam dan lama penggaraman sesuai dengan syarat SNI-01-27212009 , untuk kadar garam perlakuan konsentrasi garam dan lama penggaraman diatas $27 \%$ dan 6 jam sudah tidak memenuhi syarat SNI-01-2721-2009. Berdasarkan pengujian organoleptik didapatkan bahwa perlakuan dengan penambahan konsentrasi garam $34 \%$ dan lama penggaraman 6 jam memberikan hasil terbaik untuk indikator kenampakan, bau, dan tekstur. Pengujian organoleptik indikator rasa dengan konsentrasi garam 27\% dan lama penggaraman 3 jam memberikan hasil yang baik. Untuk konsentrasi dan lama penggaraman memberikan pengaruh yang sangat lemah terhadap indikator kenampakan, bau, dan tesktur, untuk indikator rasa konsentrasi dan lama penggaraman memberikan pengaruh yang kuat. Sedangkan untuk pengujian kimia konsentrasi garam dan lama penggaraman memberikan pengaruh kuat yaitu konsentrasi $27 \%$ dengan lama penggaraman 3 jam terhadap kadar protein dan kadar garam, untuk kadar air konsentrasi dan lama penggaraman memberikan pengaruh yang sangat lemah yaitu konsentrasi $27 \%$ dengan lama penggaraman 6 jam.
\end{abstract}

Kata Kunci: Konsentrasi Garam, Lama Penggaraman, Ikan Asin.

\section{Abstract}

This study aims to evaluate and analyze the effect of salt concentration and salting time on the quality and organoleptic value of dried salted flying fish. This study is (Factorial RAL) which consists of two factors. Factor A with salt concentration (27\%, 34\%, and 41\%) and Factor B with salting time (3 hours, 6 hours, and 24 hours) were carried out with 9 treatments and 3 replications. The variables observed were water content test, protein content test, salinity test, and organoleptic test. The analysis technique used in this study was analysis of variance which was processed using SPSS version 22. The results of the study were to test the moisture content and protein content by adding salt concentration and salting time in accordance with the requirements of SNI-01-2721-2009, for salinity salt 
concentration and salting time above $27 \%$ and 6 hours dide not meet the requirements of SNI-01-2721-2009. Based on organoleptic testing, it was found that the treatment with the addition of 34\% salt concentration and salting time of 6 hours gave the best results for indicators of appearance, odor, and texture. The organoleptic test of flavor indicators with a salt concentration of $27 \%$ and the duration of salting 3 hours gave good results. For multiple linear regression analysis the concentration and duration of salting had a very weak effect on the indicators of appearance, odor, and texture, for indicators of taste concentration and the duration of salting had a strong influence. Whereas the chemical test of salt concentration and salting time gave a strong influence, namely the concentration of $27 \%$ with a length of 3 hours salting to protein content and salt content, for water content concentration and salting time gave a very weak effect, namely the concentration of $27 \%$ with 6 hours salting time.

Keywords: Salt Concentration, long Salting, Salted Fish.

\section{Latar Belakang}

Perairan yang luas membuat Indonesia memiliki potensi perikanan yang cukup besar (Hartoyo, dkk., 2002). Sumber daya perairan umum yang dapat dimanfaatkan untuk pengembangan budi daya perikanan meliputi: perairan tawar seperti sungai, waduk, saluran irigasi teknis, rawa, dan danau, perairan payau seperti tambak, hutan bakau, dan perairan laut, sehingga banyak jenis (spesies) ikan yang hidup atau menghuni diperairan umum (Cahyono, 2001). Ikan merupakan salah satu sumber protein yang sangat dibutuhkan manusia. Kandungan protein ikan sangat tinggi dan kadar lemaknya lebih rendah jika dibandingkan dengan sumber protein hewani yang lain. Selain itu, harga ikan juga relatif lebih murah.

$\begin{array}{llr}\text { Sehingga } & \text { ikan menjadi menu } \\ \text { makanan yang } & \text { sangat disukai oleh } \\ \text { masyarakat pada umumnya. Selain itu, }\end{array}$ ikan memiliki kekurangan yaitu lebih mudah rusak dan memiliki daya tahan penyimpanan yang tidak lama pada suhu ruang. Sehingga diperlukan sebuah proses pengolahan lebih lanjut agar dapat memperpanjang daya simpannya (Nurjani, dkk,. 2009).

Salah satu kabupaten di Sulawesi Barat, yaitu Kabupaten Majene memiliki sumber daya di sektor perikanan dengan hasil tangkapan yaitu ikan terbang. Hal ini didukung oleh daerah pesisir dengan luas perairan mencapai $1.000 \mathrm{~km}^{2}$ _dan total tambak seluas 450 hektar dimana 270 Hektar di antaranya telah berproduksi. Jenis komoditi unggulan terdiri dari komoditi perikanan tangkap yaitu ikan tuna, cakalang, tongkol, layang, dan ikan terbang, serta komoditi perikanan budidaya yang terdiri dari udang windu dan ikan bandeng.

Ikan terbang (Hirudincthys oxycephalus) yang dikenal dengan nama daerah ikan Torani (Makassar), Tuingtuing (Bugis), Caeqeng (Mandar), adalah salah satu jenis ikan pelagis_kecil (ikan permukaan) yang hidup pada laut dalam kawasan tertentu. Menurut hasil penelitian dari Lembaga Ilmu Pengetahuan Indonesia (LIPI) dan Laporan Kementrian Kelautan dan Perikanan (KKP) bahwa diperairan Indonesia terdapat tiga kawasan yang merupakan habitat ikan terbang, yaitu laut Seram (Fak-fak), Laut Flores dan Selat Makassar (2011). Secara sosial ekonomi Ikan terbang ini sangat penting bagi kehidupan masyarakat di Majene, sebagai contoh Desa Mosso dan Desa Somba, Kecamatan Sendana Kabupaten Majene, Provinsi Sulawesi Barat, dimana hampir seluruh penduduknya menggantungkan hidup dari usaha penagkapan dan pengolahan (penggaraman, pengeringan, dan pengasapan) serta pemasaran ikan terbang.

Di Kabupaten Majene, ikan terbang diolah hanya dengan 2 produk unggulan yaitu ikan terbang asap dan ikan terbang asin kering. Daya simpan suatu produk juga sangat mempengaruhi kualitas 
produk dan nilai jual, maka dari itu diperlukan suatu pengolahan yang membantu agar kualitas daya simpan produk hasil perikanan bisa tahan lama dalam waktu jangka panjang. Ikan terbang dianggap memiliki nilai jual rendah dikarenakan yang menjadi prioritas pemanfaatan adalah telur dari ikan terbang. Pada umumnya ikan terbang hanya diolah menjadi ikan asin sehingga nilai jual cukup rendah. Salah satu alternatif untuk meningkatkan nilai jual ikan terbang adalah dengan melakukan pengolahan ikan menjadi abon ikan (Jayadi, A. dkk,. 2016). pPembuatan ikan asin kering merupakan pengawetan yang paling sederhana. Ikan asin kering merupakan produk ikan yang cukup mudah dalam pembuatannya. Jeroan dan sisik ikan dibuang, kemudian ditambahkan garam setelah itu kemudian dijemur atau dikeringkan (Yuarni, D,. dkk,. 2015). Salah satu cara untuk meningkatkan konsumsi masyarakat terhadap jenis ikan terbang- yaitu diversifikasi jenis makanan menjadi ikan asin kering, karena umumnya ikan asin telah dikenal luas dan mudah pengolahannya. Namun, pengolahan ikan asin kering oleh masyarakat masih secara tradisional dan belum terstandar sehingga penggunaan konsentrasi dan lama penggaraman berbeda berdasarkan individu. Tingkat penerimaan atau kesukaan konsumen terhadap ikan terbang asin kering ini perlu diperhatikan, karena penerimaan konsumen menjadi salah satu faktor yang berpengaruh pada konsumsi suatu bahan pangan. Oleh karena itu perlu dilakukan penelitian mengenai pengaruh konsentrasi garam dan lama penggaraman terhadap mutu ikan terbang asin kering dan tingkat kesukaan (uji hedonik) ikan terbang (Hirundichthys oxchepalus) asin kering.

\section{Tujuan Penelitian}

Penelitian ini bertujuan untuk mengevaluasi dan menganalisis pengaruh berbagai konsentrasi dan lama penggaraman terhadap mutu ikan terbang asin kering.

\section{Bahan dan Metode}

\section{Jenis Penelitian}

Jenis Penelitian ini termasuk penelitian eksperimen dengan pendekatan kuantitatif. Pendekatan penelitian merupakan langkah-langkah dalam melaksanakan penelitian, dalam penelitian ini akan diteliti pengaruh variabel tertentu dalam kondisi yang dikontrol. Rancangan percobaan yang digunakan dalam penelitian ini adalah Rancangan Acak Lengkap (RAL) Faktorial dengan dengan dua faktor, terdiri dari 9 perlakuan dengan 3 kali ulangan, sehingga didapatkan 27 perlakuan.

\section{Tempat dan Waktu Penelitian}

Pembuatan ikan terbang asin kering dengan uji organoleptik dilaksanakan di Laboratorium Pendidikan Teknologi Pertanian Fakultas Teknik Universitas Negeri Makassar. Sedangakan untuk analisis proksimat mengenai uji kadar air, kadar garam, kadar protein dilakukan di Laboratorium Kimia dan Makanan Ternak Fakultas Peternakan Universitas Hasanuddin. Analisis cemaran mikroba dilakukan di Laboratorium Mikrobiologi Fakultas Matematikan dan Ilmu Pengetahuan Alam Universitas Negeri Makassar.

\section{Alat dan Bahan}

Alat-alat yang digunakan dalam pengolahan ikan asin ini meliputi: Timbangan analitik, timbangan, baskom, pisau, talenan, ember plastik, stopwacth, kompor, wajan, sodet, tabung gas, room drying, wadah, dan thermometer. Bahanbahan yang digunakan dalam pembuatan ikan asin adalah ikan terbang, garam dapur atau garam komsumsi, air bersih dan minyak goreng. 
JPTP Jurnal Pendidikan Teknologi Pertanian

Prosedur Penelitian

\section{Penyiangan ikan terbang}

Perlakuan penyiangan ikan terbang yaitu pertama-tama ikan terbang ditimbang sebanyak 100 gr. Kemudian ikan di-siangi dengan air mengalir dan dibuang semua isi perut ikan. Dan ditiriskan hingga ikan tidak terlalu banyak mengandung air.

\section{Penambahan garam pada ikan terbang}

Penambahan garam pada ikan terbang yang telah diberihkan yaitu; $27 \%$, $34 \%$, dan $41 \%$. Dicampur secara merata pada ikan yang telah di-bersihkan.

\section{Perendaman ikan terbang dengan garam}

Ikan terbang yang telah diberikan garam sesuai konsentrasi garam yang di inginkan. Lama perendaman atau penggaraman yang dilakukan yaitu 3 jam, 6 jam, dan 24 jam. Setelah waktu penggaraman telah selesai dilanjutkan dengan proses pengeringan ikan. Ikan yang telah diberikan garam dan dilakukan perendaman, terlebih dahulu dilakukan pembilasan ikan dengan air mengalir agar kristal-kristal garam yang masih menempel pada ikan tersebut hilang.

\section{Pengeringan ikan asin}

Ikan asin yang telah diberikan konsentrasi garam dan lama perlakuan sesuia yang diinginkan. Ikan selanjutnya di keringkan di ruangan roomdrying dengan suhu $30^{\circ} \mathrm{C}$ sampai $55^{\circ} \mathrm{C}$ dengan lama pengeringan 3 sampai dengan 5 hari hingga didapatkan ciri-ciri ikan asin yang diinginkan.

\section{Teknik Pengumpulan dan Analisis Data}

Teknik pengumpulan data yang dilakukan dalam penelitian ini menggunakan pengamatan dan pencatatan secara sistematis terhadap subjek penelitian.
Teknik analisis data dilakukan berdasarkan analisis sidik ragam yang digunakan meliputi uji persyaratan analisis yang terdiri dari uji normalitas dan homogenitas. Apabila data yang diperoleh bersifat normal Apabila data yang diperoleh bersifat normal dan homogen maka akan dilanjutkan dengan uji statistik sidik ragam anova. Jika $\mathrm{H} 1$ diterima maka akan dilakukan uji lanjut dengan menggunakan uji Duncan pada taraf signifikan $\alpha=0,05$. Data diolah menggunakan sppss versi 22.

\section{Hasil dan Pembahasan}

\section{Evaluasi Konsentrasi dan Lama Penggaraman yang Terbaik}

\section{Kenampakan}

berdasarkan hasil penelitian tersebut, menunjukkan bahwa perlakuan dengan konsentrasi $34 \%$ dengan lama penggaraman 6 jam menjadi perlakuan terbaik menurut panalis.

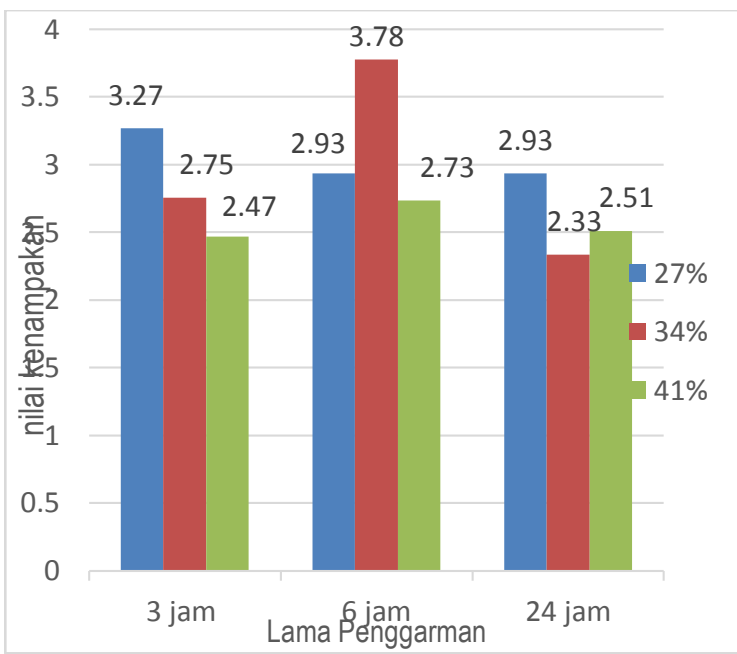

Gambar 1.Tingkat kesukaan panelis terhadap kenampakan ikan asin kering

Hal ini dikarenakan ikan dikeringkan dalam waktu yang lama bau khas dari ikan hilang. Namun, setiap ikan memiliki bau khas yang berbeda-beda. Menurut Albert (2013), bahwa pemberian konsentrasi larutan garam dan lama pengeringan dapat mempengaruhi nilai bau dari ikan layang asin, dimana semakin 
tinggi konsentrasi garam dan semakin lama proses pengeringan maka semakin tinggi bau tersebut yang disebabkan semakin kurangnya kadar air dalam daging ikan sehingga bau asli dari pada ikan (bau anyir) mengilang dan bau yang ditimbulkan akibat garam lebih terasa.

Menurut Muhlis, A. Dkk,. (2016), tingkat kesukaan panelis cenderung menurun seiring berkurangnya konsentrasi garam pada produk ikan lele sangkuriang asap dan sebaliknya semakin bertambahnya konsentrasi garam pada ikan lele sangkuriang asap semakin meningkatkan nilai kesukaan panelis terhadap warna ikan lele sangkuriang asap yang dihasilkan.

\section{Bau}

Berdasarkan hasil penelitian, perlakuan dengan konsentrasi garam 34\% dengan lama penggaraman 6 jam menjadi perlakuan terbaik menurut tingkat kesukaan panelis.

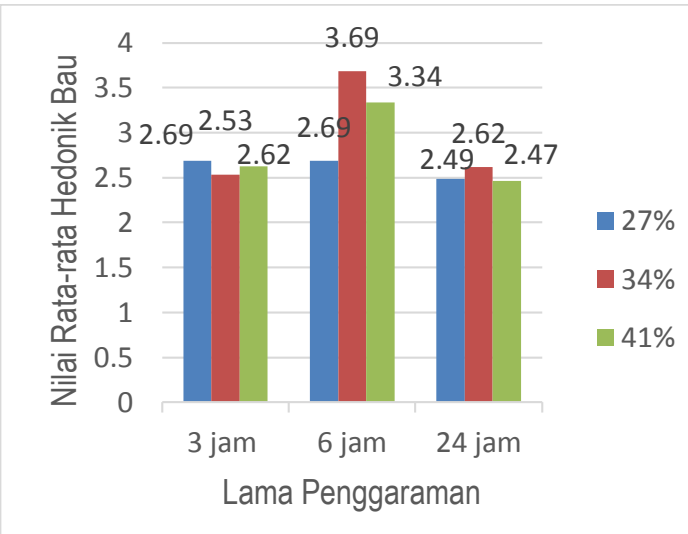

Gambar 2. Tingkat kesukaan panelis terhadap Bau ikan terbang asin kering

Hal ini dikarenakan ikan dikeringkan dalam waktu yang lama bau khas dari ikan hilang. Namun, setiap ikan memiliki bau khas yang berbeda-beda. Menurut Albert (2013), bahwa pemberian konsentrasi larutan garam dan lama pengeringan dapat mempengaruhi nilai bau dari ikan layang asin, dimana semakin tinggi konsentrasi garam dan semakin lama proses pengeringan maka semakin tinggi bau tersebut yang disebabkan semakin kurangnya kadar air dalam daging ikan sehingga bau asli dari pada ikan (bau anyir) mengilang dan bau yang ditimbulkan akibat garam lebih terasa.

Menurut Winarno (1997), molekulmolekul lemak yang mengandung radikal asam lemak tidak jenuh mengalami oksidasi dan menjadi tengik. Bau tengik yang tidak sedap disebabkan oleh pembentukan senyawa-senyawa hasil pemecahan hidroperoksida.

\section{Tekstur}

Berdasarkan hasil penelitian, perlakuan dengan konsentrasi garam 34\% dengan lama penggaraman 6 jam menjadi perlakuan terbaik menurut tingkat kesukaan panelis.

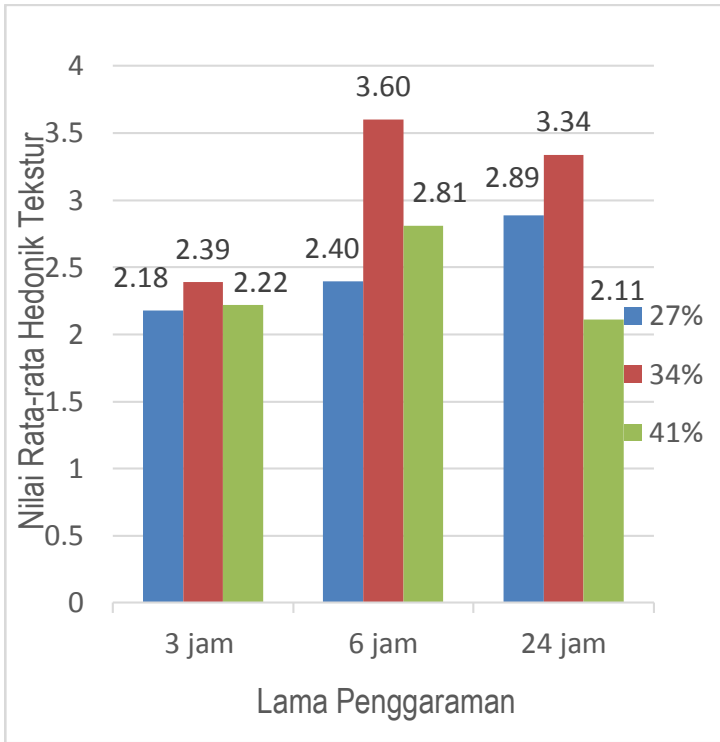

Gambar 3. Tingkat kesukaan panelis terhadap tekstur ikan terbang asin kering

Salah satu parameter mutu yang sangat berperan dalam menampilkan karakteristik ikan asin adalah tekstur. Tekstur bisa dirasakan sensasi kenyal, keras, lembut, empuk, atau alot dan lengket, halus atau kasar berpasir dan lainnya. Tekstur ikan asin yang bagus adalah padat, kompak, lentur dan cukup kering (Yuarni, D,. dkk,. 2015).

Menurut purnomo (1995) dalam Riansyah, dkk,. (2013) menjelaskan bahwa kadar air dan aktivitas air dalam pangan sangat besar peranannya terutama dalam 
membentuk tekstur bahan pangan. Oleh karena itu, jika waktu yang digunakan kurang minimum maka kadar air masih tinggi sehingga tekstur ikan kurang kering. Sebaliknya jika waktu yang digunakan terlalu lama kadar air pada ikan semakin menurun mengakibatkan ikan menjadi memiliki tekstur sangat keras, sehingga dibutuhkan waktu yang tepat untuk mengeringkan ikan.

\section{Rasa}

Berdasarkan hasil penelitian, perlakuan penambahan konsentrasi $27 \%$ dengan lama penggaraman 3 jam menjadi perlakuan terbaik menurut tingkat kesukaan panelis.

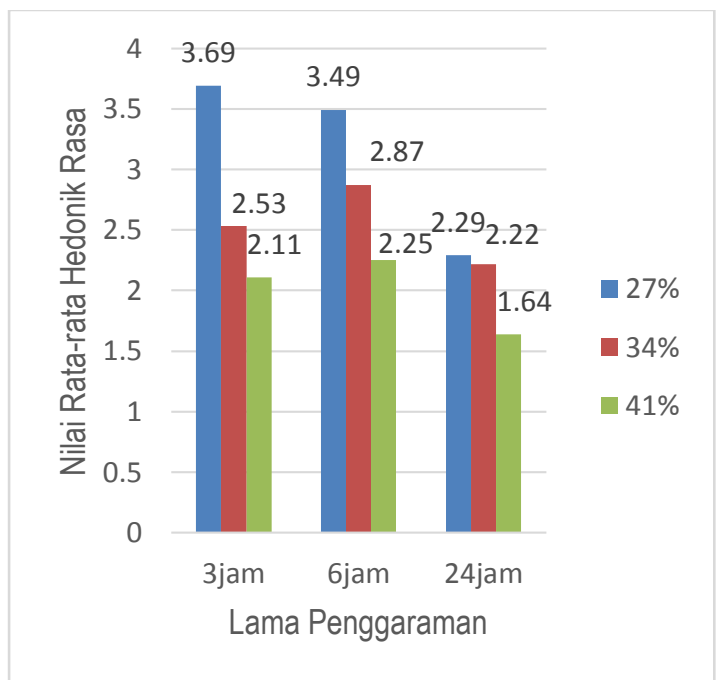

Gambar 4. Tingkat kesukaan panelis terhadap rasa ikan terbang asin kering

Rasa yang terdapat pada ikan asin dikarenakan penambahan garam yang merupakan bahan yang ditambahkan pada pembuatan ikan asin yang memberikan rasa asin. Rasa dapat diciptakan dari sumber alami seperti tanaman atau sintetis. Menurut Padaga dan Sawitri (2005), rasa sangat mempengaruhi kesukaan konsumen terhadap es krim, bahkan dapat dikatakan merupakan faktor penentu utama. Rasa es krim dipengaruhi oleh beberapa hal seperti bahan pengental yang dapat mengurangi rasa manis gula dan perubahan tekstur yang dapat mengubah cita rasa es krim (Satriani, dkk,. 2018).
Semakin banyak konsentrasi dan lama penggaraman yang diberikan semakin berpengaruh terhadap rasa yang dihasilkan. Menurut Rahmani, dkk,. (2007) menyatakan bahwa tingkat kesukaan panelis terhadap ikan asin cenderung semakin menurun dengan meningkatnya lama penggaraman, karena garam yang meresap kedalam daging ikan semakin banyak sehingga menimbulkan rasa yang lebih asin.

\section{Kadar Air}

Hasil penelitian menunjukkan bahwa kadar air meningkat dan menurun seiring dengan pemberian konsentrasi garam dan lama penggaraman. Secara umum, keseluruhan perlakuan konsentrasi dan lama penggaraman memenuhi syarat mutu standar SNI 01-2721-2009 yaitu maksimal 40\%, Kadar air yang dihasilkan pada penelitian ini berkisar antara 16,83 $32,49 \%$. Berdasarkan dari hasil penelitian dapat diketahui bahwa perlakuan konsentrasi garam dan lama penggaraman terbaik menurut SNI 012721-2009 diperoleh perlakuan konsentrasi garam $41 \%$ dengan lama penggaraman $3 \mathrm{jam}$.

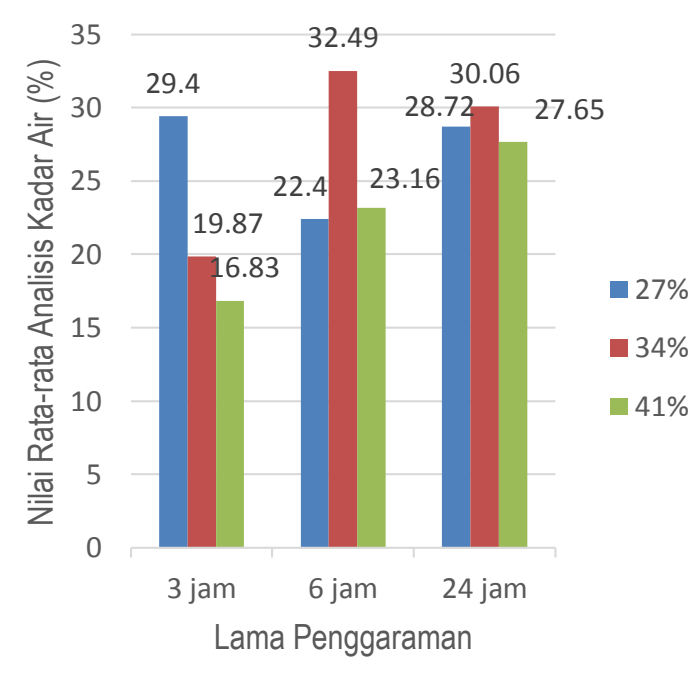

Gambar 5. Grafik Analisis Kadar Air Ikan terbang Asin kering.

Hasil analisis sidik ragam menunjukkan bahwa nilai $\mathrm{F}$ hitung $>\mathrm{F}$ tabel pada konsentrasi dan lama 
JPTP Jurnal Pendidikan Teknologi Pertanian

penggaraman berpengaruh nyata terhadap kadar air ikan asin, sehingga dilanjutkan uji duncan, Data Hasil uji duncan menunjukkan bahwa perlakuan terbaik pada konsentrasi $27 \%$ dan lama penggaraman 24 jam. Hal ini terjadi karena semakin besar konsentrasi garam maka semakin banyak pula molekul air yang ditarik keluar oleh ion hidrat, karena dalam bahan pangan garam terisolasi dan menarik sejumlah air. Kadar air ikan asin cenderung turun dengan meningkatnya lama penggaraman. Semakin lama daging ikan direndam dalam larutan garam maka air yang keluar dari bahan semakin banyak.

Menurut Witono, dkk,. (2013), menyatakan bahwa pengeluaran air selama osmosis dipengaruhi oleh suhu dan konsentrasi awal $\mathrm{NaCl}$. Kandungan kadar air pada ikan asin dengan perlakuan konsentrasi $41 \%$ dan 3 jam sudah memenuhi SNI terhadap kandungan kadar air ikan asin. Pada SNI 01-2721-2009 dicantumkan bahwa persyaratan mutu ikan asin kering maksimal 40\% (\%bb). Sejalan dengan pendapat Taib dkk,. (1997) dalam Fitriani (2008), bahwa kemampuan bahan untuk melepaskan air dari permukaannya akan semakin besar dengan meningkatnya suhu udara pengering yang digunakan dan makin lama proses pengeringan, sehingga kadar air yang dihasilkan semakin rendah. Hal ini juga sesuai dengan pernyataan Riansyah, dkk,. (2013) yang menyatakan bahwa semakin tinggi suhu dan lamanya waktu pengeringan yang diberikan, memberikan pengaruh yang sangat besar terhadap kecepatan perpindahan air ikan asin sepat siam.

Menurut Rachmawan (2001), bahwa semakin tinggi suhu dan kecepatan aliran udara pengeringan makin cepat pula proses pengeringan berlangsung. Makin tinggi suhu udara pengering, makin besar energi panas yang dibawa udara sehingga makin banyak jumlah massa cairan yang diuapkan dari permukaan bahan yang dikeringkan. Proses pengeringan berlangsung sampai kesetimbangan
Volume 5, 2019

dicapai antara permukaan dalam dan permukaan luar bahan antara permukaan luar bahan dengan lingkungan (Ramadani, W,R. dkk,. 2015).

\section{Kadar Protein}

Hasil penelitian menunjukkan bahwa perlakuan dengan konsentrasi garam $41 \%$ dan lama penggaraman 3 jam menjadi perlakuan terbaik menurut syarat SNI dengan nilai kadar protein minimal $40 \%$.

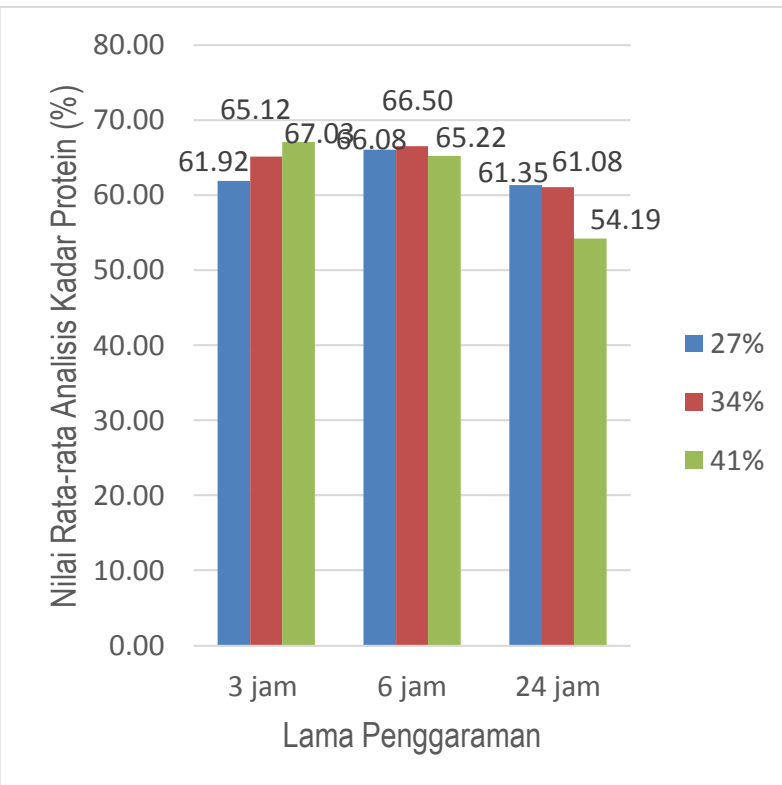

Gambar 6 Grafik Analisis Kadar Protein Ikan terbang asin kering.

Hasil analisis sidik ragam menunjukkan bahwa nilai $\mathrm{F}$ hitung $>\mathrm{F}$ tabel pada konsentrasi dan lama penggaraman berpengaruh nyata terhadap kadar air ikan asin, sehingga dilanjutkan uji duncan, Data Hasil uji duncan menunjukkan bahwa perlakuan terbaik pada konsentrasi $27 \%$ dan lama penggaraman 3 jam. Hasil penelitian menunjukkan bahwa kadar protein meningkat dengan meningkatnya konsentrasi garam dan lama penggaraman. Pada konsentrasi rendah menyebabkan protein mengalami salting in dan pada konsentrasi tinggi protein mengalami salting out. Pada proses salting in protein akan lebih mudah larut, sebaliknya pada peristiwa salting out protein akan mengendap dan tidak mudah larut. 
Kadar protein ikan asin cenderung meningkat dengan meningkatnya lama penggaraman. Hal ini disebabkan proses salting out sehingga daya larut protein berkurang. Akibatnya protein terpisah sebagai endapan (Winarno, 2002). Selain itu, garam mempunyai tekanan osmotik yang tinggi sehingga dapat menarik air dari daging ikan (Anonim, 2003). Dengan demikian menurunnya kadar air ikan asin, maka kadar protein akan meningkat. Penambahan garam dalam pengolahan ikan asin dapat mempengruhi kadar air ikan asin, ikan asin akan mengakibatkan meningkatnya kandungan protein. Hal ini disebabkan oleh garam yang diserap kedalam daging ikan mendenaturasi larutan koloid proteinshinggal terjadi koagulasi yang membebaskan air keluar dari daging ikan (Yuarni, D, dkk,. 2015). Menurut Adawyah (2007) dalam Riansyah, dkk,. (2013), kadar air yang mengalami penurunan akan mengakibatkan kandungan protein didalam bahan mengalami peningkatan. Dengan adanya penambahan garam dalam pengolahan ikan asin juga dapat mempengaruhi kadar air ikan asin, maka kadar garam yang terserap ke dalam daging ikan akan menurunkan kadar air ikan asin dan mengakibatkan meningkatnya kandungan protein.

\section{Kadar Garam}

Berdasarkan hasil penelitian, pemberian konsentrasi $41 \%$ dengan lama penggaraman 24 jam menjadi perlakuan dengan nilai tertinggi.

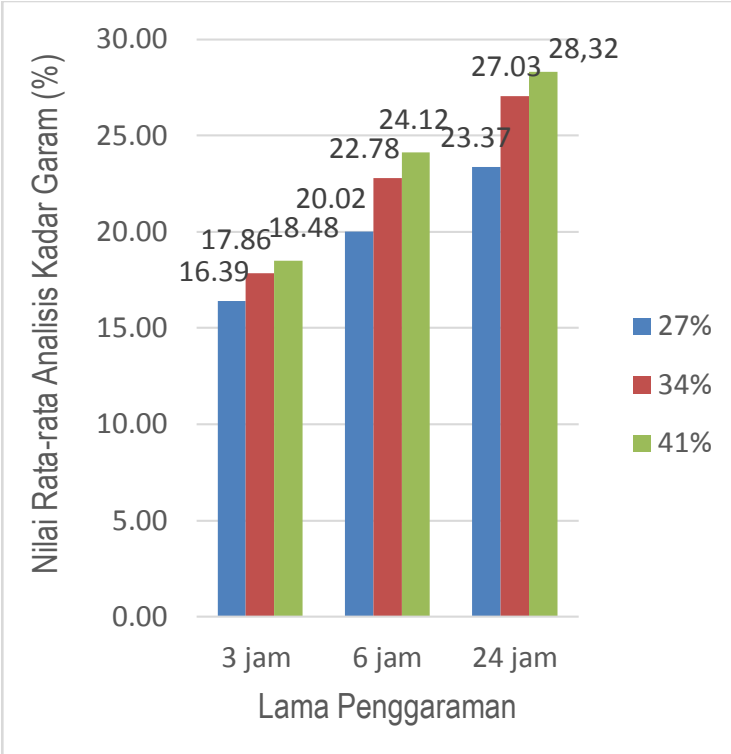

Gambar 7. Grafik Analisis Kadar Garam Ikan terbang asin kering.

Hasil analisis sidik ragam menunjukkan bahwa nilai $\mathrm{F}$ hitung $>\mathrm{F}$ tabel pada konsentrasi dan lama penggaraman berpengaruh nyata terhadap kadar air ikan asin, sehingga dilanjutkan uji duncan, Data Hasil uji duncan menunjukkan bahwa perlakuan terbaik pada konsentrasi $41 \%$ dan lama penggaraman 24 jam. Dari hasil tersebut dapat diketahui bahwa kadar garam cenderung meningkat seiring dengan semakin banyaknya konsentrasi garam dan lamanya waktu penggaraman. Perubahan terjadi bergantung pada jumlah garam yang ditambahkan dalam proses penggaraman dan lama waktu penggaraman, semakin lama penggaraman maka tingkat denaturasi protein semakin tinggi dan kadar garam semakin meningkat (Safrullah, 2018). Menurut Suprapti (2002), Garam merupakan faktor utama dalam proses pengasinan telur, berfungsi sebagai bahan pengawet untuk mencegah pembusukan telur, sehingga meningkatkan daya simpannya. Semakin tinggi kadar garam yang diberikan pada proses pengasinan telur maka semakin meningkatkan daya simpannya.

Menurut Paparang (2013) bahwa pemgaruh konsentrasi garam terhadap kadar air pada daging ikan peda 
JPTP Jurnal Pendidikan Teknologi Pertanian

mengalami penurunan dengan bertambahnya konsentrasi garam.

\section{Simpulan}

Berdasarkan hasil penelitian yang telah dilakukan, maka dapat disimpulkan bahwa Penambahan konsentrasi garam dan lama penggaraman yang berbeda berpengaruh terhadap ikan terbang asin kering yang dihasilkan, ditunjukkan dengan nilai organoleptik yang dihasilkan. Perlakuan terbaik diperoleh pada konsentrasi $34 \%$ dengan lama penggaraman 6 jam pada indikator organoleptik kenampakan, bau dan tekstur. Pada pengujian organoleptik indikator rasa diperoleh perlakuan terbaik yaitu konsentrasi $27 \%$ dengan lama penggaraman 3 jam. Penambahan konsentrasi dan lama penggaraman yang berbeda berpengaruh terhadap mutu ikan terbang asin kering yang dihasilkan. pengujian kimia yaitu kadar air dan kadar protein masih sesuai dengan syarat SNI 01-2721-2009, akan tetapi untuk pengujian kadar garam pada perlakuan konsentrasi $27 \%$ diatas lama penggaraman 6 jam sudah tidak memenuhi syarat SNI 01-2721-2009.

\section{Daftar Pustaka}

Albert R. Reo. 2013. Mutu Ikan Kakap Merah yang Diolah dengan Perbedaan Konsentrasi Garam dan Lama Pengeringan. Jurnal Perikanan dan kelautan tropis, (on line), vol IX1, (http://ejournal.unsrat.ac.id), diakses 20 Mei 2014.

Anonim. 2003. Teknologi dan Pangan Badan Standarisasi Nasional, 1994. Metode Pengujian Mikrobiologi. Penentuan Angka Lempeng Total SNI 01-2339-1991.

Badan Standarisasi Nasional SNI 2725.1.2006 Tentang Cara Uji Mikrobiologi Bagian 1: Uji Escherchia coli dan Salmonella Pada Produk Perikanan. Jakarta.

1992, Standar Produk Perikanan, Standar Ikan Asin Kering, SNI 01-
Volume 5, 2019

2721-1992, BBPMHP Jakarta 1994Pengujian Mikrobiologi. Metode Pengujian Coliform dan Escherichia coli SNI 012332-1991 Produk Perikanan, BSN Jakarta.

Cahyono, B., 2001. Budidayalkan di PerairanUmum. Yogyakarta: Kanisius.

Hartoyo, D., Herie, P., \&Ikhsan, B.W., 2002. Sebaran Densitas Ikan Pelagik di Selat Bali pada Musim Timur September 1998. Unit Pelaksana Teknis Baruna Jaya. BPP Teknologi.

Jayadi, A., Anwar, B., \& Sukainah, A. 2016. Pengaruh Suhu Penyimpanan dan Jenis Kemasan terhadap Mutu Abon Ikan Terbang. Jurnal, (On line), vol II, no 01 , (http://www.ojs.unm.ac.id), diakses pada 19 November 2018.

Kementerian Kelautan dan Perikanan RI. 2011. Potensi dan Prospek pengembangan Industri Filet Ikan di Indonesia. Majalah Warta Ikan, Kementerian Kelautan dan Perikanan Indonesia, Vol. III, No. 12, BulanMaret 2011.

2012. Volume Produksi PerikananTangkap di Laut menurut Jenis Ikan. www.statistik.kkp.go.id . Di unduh pada tanggal 10 April 2018.

Muhlis, A., Kadirman. \& Mustarin, A. 2016. Penerapan berbagai Dosis Garam terhadap Mutu Ikan Lele Sangkuriang (Clarias sp) Asap Menggunakan Metode Smoke Cabinet. Jurnal, (On line), vol Ii, no 01, (http://www.ojs.unm.ac.id), diakses pada 19 Desember 2018. Universitas Universitas Negeri Makassar. Makassar.

Nurjani, A., A. R. Simanjuntak., A. Yakinuddin., H. W. Febria ningrum., Hermansyah., dan S. Mentari. 2009. 
JPTP Jurnal Pendidikan Teknologi Pertanian

Teknik Penggaraman Pindang Ikan yang baik dan benar. Teknik Penggaraman Ikan Yang Baik dan Benar. Makalah. IPB: Bogor.

Padaga, M dan M, E, Sawitri. 2005. Es krim yang Sehat. Trubus Agrisarana: Surabaya.

Paparang RW. 2013. Studi Pengaruh Variasi Konsentrasi garam terhadap citarasa peda ikan layang. Jurnal Media Teknologi Hasil Perikanan. 1(1):1-4.

Rachmawan, O. 2001. Pengeringan, Pendinginan dan Pengemasan Komoditas Pertanian. Buletin Departemen Pendidikan Nasional: Jakarta.

Rahmadani, W,R., Yahya, M., \& Jamaluddin. 2015. Perubahan Kadar Air dan Kadar Pati Ubi Kayu (Manihot utilissima) Selama Pengeringan Menggunakan Ruang Pengering. Jurnal, (On line), vol III, no 01, (http://www.ojs.unm.ac.id), diakses pada 19 Januari 2019. Universitas Negeri Makassar. Makassar.

Rahmani, Yunianta, Martati, E. 2007. Pengaruh Metode Penggaraman Basah terhadap Karakteristik Ikan Asin Gabus (Ophiocepahalus Striatus). Jurnal Teknologi Pertanian. Volume 8 Nomor 3 (Desember 2007).

Riansyah. A., Supriadi. A., \& Nopianti. R., 2013. Pengaruh Perbedaan Suhu dan Waktu Pengeringan terhadap Karakteristik Ikan Asin Sepat Siam (Trichogaster Pectoralis) Dengan Menggunakan Oven. Jurnal, (On line), vol II, no 01, (http://www.thi.fp.usri.ac.id), diakses pada 20 Mei 2014.
Volume 5, 2019

Safrullah. A. 2018. Pengaruh Konsentrasi Garam dan Lama Penyimpanan Terhadap Kandungan Protein dan Kadar Garam Telur Asin. Universitas Hasanuddin. Makassar.

Satriani,. Sukainah, A., \& Mustarin, A. 2018. Analisis Fisiko-kimia Es Krim dengan Penambahan Jagung Manis (Zeamays. L Saccharata) dan Rumput laut (Eucheuma cottoni). Jurnal, (On line), vol IV, no 01, (http://www.ojs.unm.ac.id), diakses pada 19 Desember 2018.

Syahruddin. H. 2013. Pengaruh Penggaraman Teradap Protein Ikan Layang (Decapterus rucell). Surabaya

Suprapti, M. L. 2002. Pengawetan Telur. Kanisius: Yogyakarta.

Yuarni, D. Kadirman, \& Jamaluddin. 2015. Laju Perubahan Kadar Air, Kadar Protein, dan Uji Ornagoleptik Ikan Lele Asin Menggunakan Alat Pengering Kabinet (Cabinet Dryrer) Dengan Suhu Terkontrol. Jurnal, (On line), vol I, no 01, (http://www.ojs.unm.ac.id), diakses pada 19 Desember 2018.Universitas Negeri Makassar. Makassar.

Winarno. F.G. dan B.S.L. Jennie. 1982. Kerusakan Bahan Pangan dan Cara Pencegahannya, Ghalia Indonesia. Jakarta.

Winarno, F.G. 1997. Kimia Pangan dan Gizi. Gramedia Pustaka Utama. Jakarta. 